\title{
ISSUES FACING THE SOUTH AFRICAN RESEARCH AND DEVELOPMENT SYSTEM IN THE NEXT 20 YEARS
}

\author{
S.S. Grobbelaar ${ }^{1}$ and A.J. Buys ${ }^{2}$ \\ Department of Engineering and Technology Management \\ University of Pretoria, South Africa \\ ${ }^{1}$ saartjie.grobbelaar@up.ac.za, ${ }^{2}$ andre.buys@up.ac.za
}

\begin{abstract}
There is some concern about the future ability of South Africa's Research and Development $(R \& D)$ system to produce $R \& D$ output. This paper documents a Delphi study that was conducted in order to gain insight into the opinion of experts regarding the most pressing issues facing the South African R\&D system in the next 20 years. Two main themes emerge from the study. First, experts foresee poor prospects for the retention and rejuvenation of researchers in the system. The second theme is the poor prospects for sufficient funding for $R \& D$ in the next 20 years.In general, there was a high level of agreement that the issues were critical. The exception was the respondents' opinion on the negative effect current Black Economic Empowerment policies might have on quality and R\&D capacity in the private sector.
\end{abstract}

\section{OPSOMMING}

Daar bestaan 'n mate van kommer oor die toekomstige vermoë van Suid-Afrika se Navorsing en Ontwikkeling(N\&O)-stelsel om N\&O-uitsette te lewer. In hierdie verslag word 'n Delphistudie gedokumenteer wat uitgevoer is om kenners se opinies in te win rakende die mees dringende sake wat die Suid-Afrikaanse N\&O-stelsel in die volgende 20 jaar in die gesig staar. Twee temas kom na vore in die navorsing. In die eerste plek, voorsien kenners swak vooruitsigte vir die behoud en vernuwing van personeel van die stelsel. In die tweede plek, word swak vooruitsigte in terme van voldoende befondsing vir N\&O oor die volgende 20 jaar voorsien. Oor die algemeen is 'n hoë mate van samestemming ten opsigte van die kritikaliteit van die aangeleenthede gevind. Die uitsondering was die respondente se opinie van die negatiewe effek wat huidige Swart Ekonomiese Bemagtigingsbeleid mag hê op die kwaliteit en vermoëns van $\mathrm{N} \& \mathrm{O}$ in die privaatsektor. 


\section{INTRODUCTION:}

Over time, policy decisions regarding the investment of resources in an R\&D system are made. These decisions have long-term consequences for the system, impacting its current and future ability to function and produce R\&D output. In South Africa there is concern about the sustainability of the production of R\&D output.

Recent trends show evidence of disinvestment and the decay of South Africa's R\&D capacity:

- $\mathrm{R} \& \mathrm{D}$ expenditure in SA has slipped from $1.2 \%$ of GDP in 1987 to $0.76 \%$ in 2001. This is quite low when compared with the OECD average of 2.15\% [3]. However R\&D expenditure as a percentage of GDP has shown improvement from 2001 to 2003. In the 2003/4 survey it had increased to $0.81 \%$ of GDP [1].

- There is evidence that South Africa is slipping in its position as a knowledge creator. South Africa has dropped from creating $0.8 \%$ of the world's scientific output in 1990 to only $0.5 \%$ in 2002 [3].

- A survey of the state of research equipment in South Africa also highlighted some concern that it posed a threat to the research infrastructure [2]

- More alarming is the fact that South Africa has an ageing R\&D workforce. The human resource base is not being rejuvenated: researchers in the 30-49 age cohort dropped from 77\% in 1990 to 45\% in 1998 [4].

These trends are justifiably a cause of great concern for policy makers in South Africa. In order to start addressing these issues, a clear understanding of the problems facing the system must be gained. This paper documents an investigation of the opinion of experts in the system about the most pressing issues facing South African R\&D in the next 20 years. This question was posed: "What are the hurdles facing the South African R\&D system in the next 20 years?”.

The South African R\&D system can be divided in to three main sectors: the higher education sector (HES), public sector, and private sector [5]. The research question was therefore divided into three sub-questions:

1) What are the hurdles facing the SA HES R\&D system in the next 20 years?

2) What are the hurdles facing the SA Public R\&D system in the next 20 years?

3) What are the hurdles facing the SA Private R\&D system in the next 20 years?

A Delphi study was conducted ain order to find some answers to this research question. The following section briefly summarises the methodology followed in the study.

\section{METHODOLOGY}

The Delphi method is an established research methodology that allows exploration of the expected future of novel and evolutionary phenomena. The technique obtains the most reliable consensus of opinion of a group of experts by allowing them to express their own views on a topic, but also by taking account of the views of the other 
participants by means of controlled feedback [6].

Figure 1 is a graphical representation of the process followed in the Delphi study.

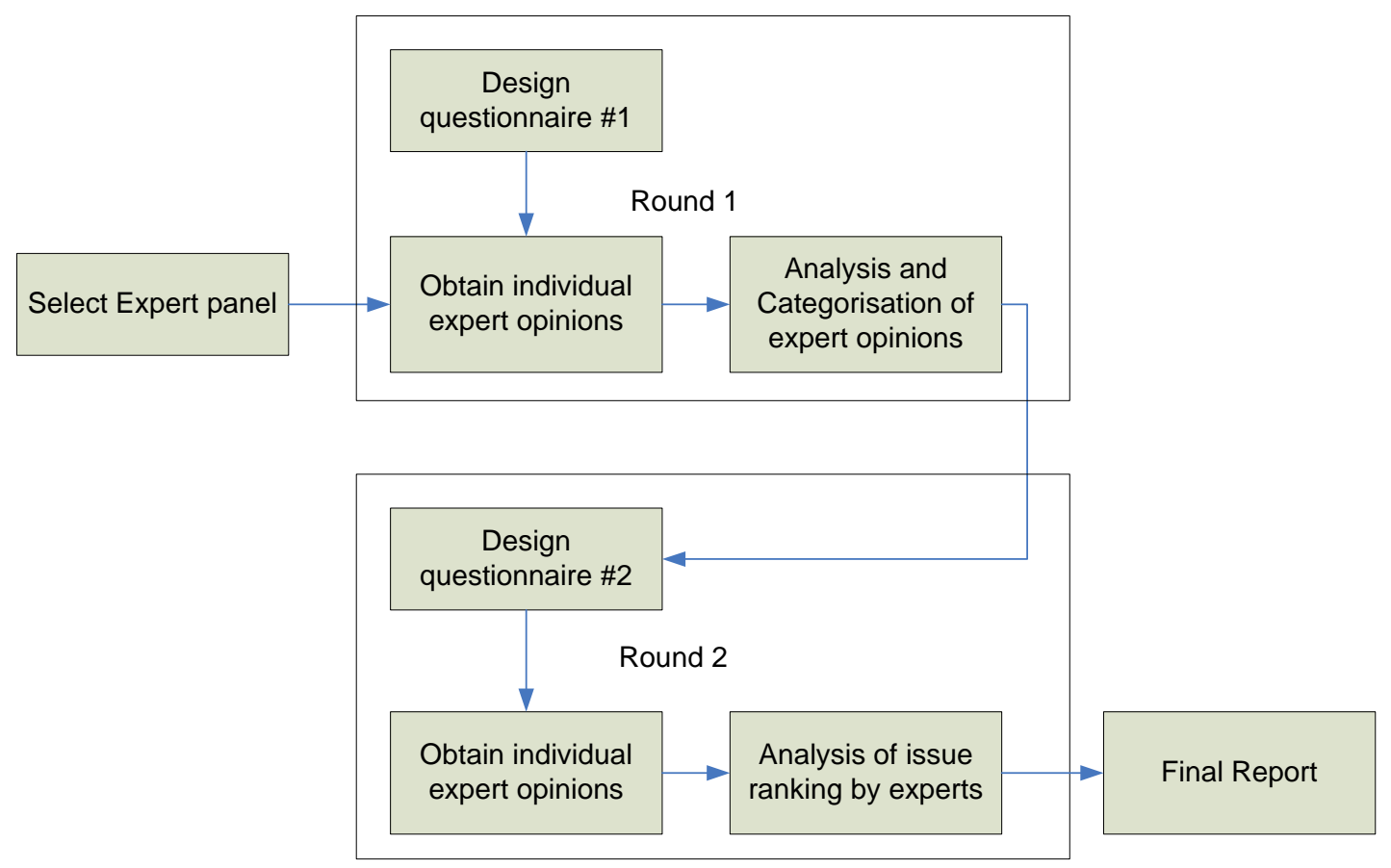

Figure 1: The Delphi process followed in the study

The study was undertaken in two rounds. This was judged to be the correct balance between wishing to reach a useful consensus, and ensuring that a significant proportion of participants completed the study.

In the first round, questionnaire respondents were asked to list some of the most pressing issues facing the South African R\&D system in the next 20 years. From the feedback received from the first round a second round survey was developed. In the development of the second round survey, the ideas generated in the first round questionnaire were categorised into 'issue' categories. In the second round survey, respondents were asked to rate the issue categories on a scale from 1 to 6 (where 1 indicates that it is a critical issue, and 6 indicates that the issue does not exist).

For the purpose of this study, a decision was made on the level of consensus reached in terms of the standard deviation, as described in the table below.

A crucial aspect of conducting a successful Delphi study is the selection of the respondents. The next section discusses the selection of the expert panel for the purpose of this Delphi study.

\section{SELECTION OF THE EXPERT PANEL}

Much care was taken in recruiting the panel. Dalkey, Rourke, Lewis \& Snyder [7] report that there is a definite increase in the reliability of group responses with 
increasing group size. Reliability, with a correlation coefficient approaching 0.9 , was found with a group size of 13. Debecq, Van de Ven \& Gustafson [8] suggest using the minimally sufficient number of respondents.

\begin{tabular}{|l|l|}
\hline St. deviation $(s)$ & Level of consensus achieved \\
\hline $0 \leq s<1$ & High level \\
\hline $1 \leq s<1.5$ & Reasonable / Fair level \\
\hline $1.5 \leq s<2$ & Low level \\
\hline $2 \leq s$ & No consensus \\
\hline
\end{tabular}

Table 1: Decision criteria for the level of consensus reached in the Delphi study

Following these recommendations, a panel of 18 experts was selected for the Delphi study in this research project. Care was also taken to ensure that the experts were representative of demographic groups of the South African population, and to include experts from all three of the R\&D sectors in the South African R\&D system (the higher education system, the public sector, and the private sector).

The study also ensured that as much variation in racial diversity as possible was included in each of the groups of people selected for the three sectors surveyed (African, White [Afrikaans, English], Indian heritage).

- Six people from the higher education sector participated in the survey. These individuals were selected for the panel based on their stature in the academic community as experts on the South African R\&D and innovation system, and their selection ensured that they were from different institutions (the Universities of Pretoria, Witwatersrand, Stellenbosch, and Cape Town).

- From the public sector six individuals participated. All hold very senior positions in their organizations (Human Sciences Research Council, Dept. of Trade \& Industry, Support Programme for Industrial Innovation, Nuclear Energy Council of S.A., Dept. of Science \& Technology, National Advisory Council on Innovation).

- From the private sector six R\&D experts were selected. They included individuals from the innovation hub, entrepreneurs/innovators, independent innovation consultants, and the managing director of a technology company. Many of these industry experts also play advisory roles to senior government officials.

The following sections discuss the outcome of the Delphi study.

\section{OUTCOME OF DELPHI STUDY FOR THE HIGHER EDUCATION SECTOR}

The following table is a summary of the aggregated respondent opinion regarding the level of criticality of issues facing the R\&D system in South Africa's Higher 
Education Sector (HES) over the next 20 years.

\begin{tabular}{|c|c|c|c|c|}
\hline Issue category & Median $^{1}$ & Mean $^{2}$ & Mode $^{3}$ & St. Dev \\
\hline $\begin{array}{l}\text { 1. Inability to Retain and Rejuvenate } \\
\text { HR stock in the system }\end{array}$ & 1.00 & 1.50 & 1.00 & 0.69 \\
\hline 2. Lack of funding for R\&D in the HES & 2.00 & 2.39 & 2.00 & 1.06 \\
\hline $\begin{array}{l}\text { 3. Deterioration of quality of Human } \\
\text { Resources working in R\&D in the } \\
\text { sector }\end{array}$ & 2.00 & 2.39 & 1.00 & 1.11 \\
\hline $\begin{array}{l}\text { 4. Poor Linkages pose a threat to future } \\
\text { capacity and the relevance of } R \& D \\
\text { performed in the system }\end{array}$ & 3.00 & 2.56 & 3.00 & 0.83 \\
\hline $\begin{array}{l}\text { 5. The lack of Female and black } \\
\text { Researchers for R\&D to reach } \\
\text { representative work force }\end{array}$ & 2.00 & 2.61 & 2.00 & 1.42 \\
\hline 6. Inadequate funding of equipment & 3.00 & 3.22 & 4.00 & 0.97 \\
\hline $\begin{array}{l}\text { 7. Lack of multi-disciplinary research } \\
\text { projects }\end{array}$ & 3.00 & 3.22 & 2.00 & 1.55 \\
\hline $\begin{array}{l}\text { 8. Difficulty of successful R\&D policy } \\
\text { alignment with National priorities. }\end{array}$ & 3.00 & 3.28 & 3.00 & 1.15 \\
\hline
\end{tabular}

Table 2: Summary table of hurdles facing the HES R\&D in the next 20 years

The level of consensus achieved by the group is measured by considering the standard deviation of opinion. It can be concluded that an overall reasonable level of agreement exists regarding the issues in the system.

Respondents failed to agree on the criticality of the hurdle posed to the system by a perceived lack of multi disciplinary research in the sector (St. dev 1.55). This issue could therefore be identified as an area of further discussion and debate.

It can be concluded from the summary in Table 2 that the most pressing issues facing the South African HES relate to the human resources for R\&D in the sector. A high level of consensus (St dev of 0.69) was achieved that the inability to retain and rejuvenate the Human Resources stock could pose a major hurdle to the system in the next 20 years. Another major issue facing the system is the perceived deterioration of quality of human resources working in the system - resulting from a multiple of sources such as a lack of good remuneration and career opportunities of researchers.

The section below discusses the outcome of the Delphi study for the public sector.

\footnotetext{
${ }^{1}$ Mean: The mean is calculated by adding a group of numbers and then dividing by the count of those numbers.

${ }^{2}$ Median: The middle number of a group of numbers; that is, half the numbers have values that are greater than the median, and half the numbers have values that are less than the median.

${ }^{3}$ Mode: The most frequently occurring number in a group of numbers.
} 


\section{OUTCOME OF DELPHI STUDY FOR THE PUBLIC SECTOR}

The following table is a summary of the aggregated respondent opinion regarding the level of criticality of issues facing the South Africa's public sector R\&D system over the next 20 years.

\begin{tabular}{|c|c|c|c|c|}
\hline Issue category & Median & Mean & Mode & St. Dev \\
\hline $\begin{array}{l}\text { 1. Inability to retain and rejuvenate the } \\
\text { researchers' stock in the system }\end{array}$ & 2 & 2.11 & 1 & 1.20 \\
\hline $\begin{array}{l}\text { 2. Lack of government funding to public } \\
\text { sector to develop R\&D and technology } \\
\text { platforms }\end{array}$ & 2 & 2.56 & 2 & 1.17 \\
\hline $\begin{array}{l}\text { 3. Deterioration of quality of human resources } \\
\text { working in } R \& D\end{array}$ & 2 & 2.61 & 2 & 1.11 \\
\hline $\begin{array}{l}\text { 4. There is a lack of direction and leadership } \\
\text { in science policy. }\end{array}$ & 3 & 3.28 & 2 & 1.66 \\
\hline $\begin{array}{l}\text { 5. Current BEE policies will have a negative } \\
\text { effect on quality and R\&D capacity. }\end{array}$ & 3.5 & 3.33 & 4 & 1.76 \\
\hline
\end{tabular}

Table 3: Summary table of hurdles facing the rublic sector $R \& D$ in the next 20 years

Considering the standard deviation of opinion used to measure the level of consensus, it can be concluded that overall there is a reasonable level of agreement about the criticality of issues.

An exception is the respondents' opinion on the effect that current BEE policies (standard deviation is 1.76) and a perceived lack of direction and leadership in science policy (standard deviation is 1.66) might have on quality and R\&D capacity in the public sector. Figure 2 shows a graphical representation of respondent opinion regarding these issues.

Interestingly, the group opinion seems to be divided between two schools of thought about the effect BEE policies might have on the future R\&D capacity of the public sector. Some respondents believe that too much attention is given to racial quotas, and not enough to competence as a functional goal of policy instruments. A second group does not think that BEE policies pose any real threat to quality and future R\&D capacity.

Although a large proportion of the respondents agree that there is lack of leadership in science policy - that is, a lack of credible foresight leading to a constant refocusing on the short term - a number of respondents do not agree. The second group is of the opinion that there is no lack in the formulation of good policies for the system, but that implementation in current structures seems to be a major headache, owing to organisational inertia and the lack of expertise in the people working in the system. 

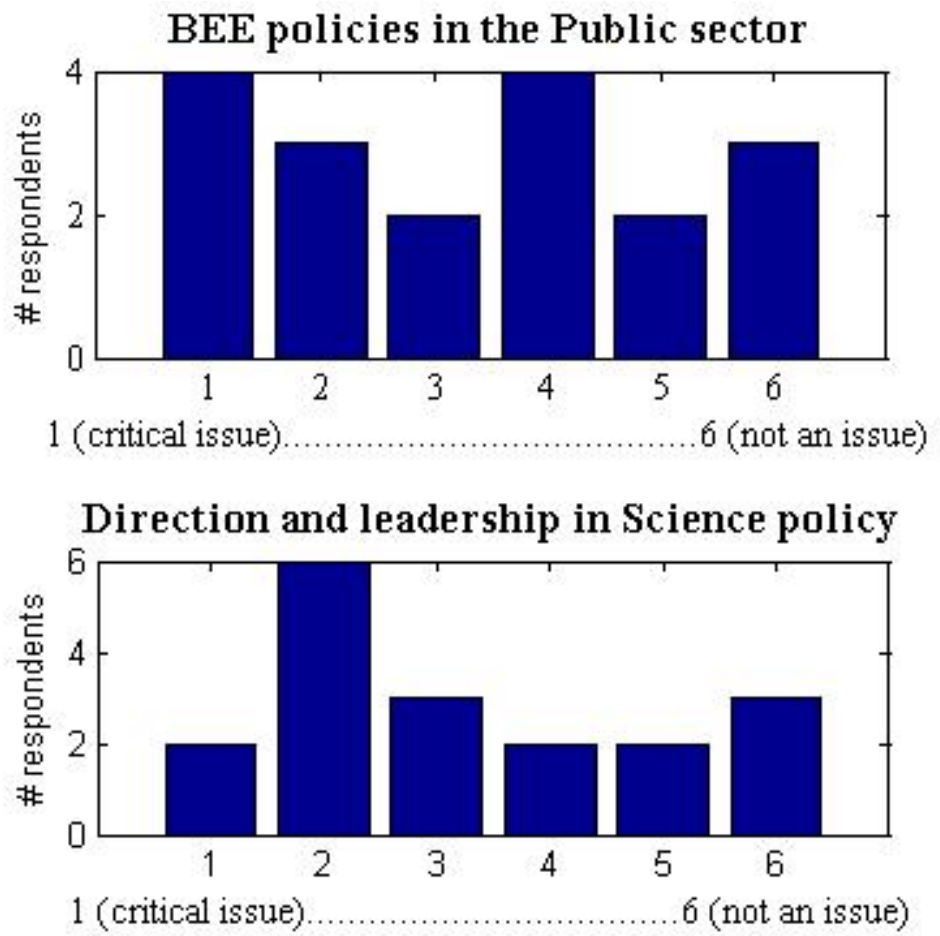

\section{Figure 2: Public sector opinion regarding BEE policies and direction and leadership in science policy}

It can be concluded from the summary in Table 2 that the most pressing issues facing the South African public sector concern human resources. Respondents agreed that the prospects for retaining and rejuvenating the human resources stock in the next 20 years are poor, owing (for example) to the loss of people through the brain drain; the small number of graduates interested in careers in science; and the lack of an adequate rewards system in the public sector. Again, as with the HES, another human resources issue facing the system is the perceived deterioration of the quality of human resources working in the system, caused by factors such as the lack of good remuneration and career opportunities of researchers.

\section{OUTCOME OF DELPHI STUDY FOR THE PRIVATE SECTOR}

Table 4 contains a summary of the aggregated respondent opinion about the level of criticality of issues facing the $R \& D$ system in South Africa's private sector $R \& D$ system over the next 20 years.

The level of consensus achieved by the group is measured by considering the standard deviation of opinion. It can be concluded that overall there is a reasonable level of agreement about the criticality of issues raised in the first round.

An exception is the respondent's opinion on the effect that current BEE policies (standard deviation is 1.60) and a perceived lack of direction and leadership in science policy (standard deviation is 1.49) might have on quality and R\&D capacity in the private sector. The following is a graphical representation of respondent opinion regarding these issues. 


\begin{tabular}{|l|l|l|l|l|}
\hline & Median & Mean & Mode & St. Dev \\
\hline $\begin{array}{l}\text { 1. Lack of Research culture in SA } \\
\text { 2. Inability to retain and rejuvenate the } \\
\text { Researchers stock in the system }\end{array}$ & 2 & 1.89 & 2 & 0.94 \\
\hline $\begin{array}{l}\text { 3. Lack of funding of R\&D } \\
\text { 4. Restrictive communication }\end{array}$ & 2 & 2.11 & 2 & 1.10 \\
\hline $\begin{array}{l}\text { infrastructure } \\
\text { 5. Poor Linkages }\end{array}$ & 3 & 2.17 & 1 & 1.30 \\
\hline $\begin{array}{l}\text { 6. Lack of fiscal incentives from } \\
\text { government to foster R\&D culture } \\
\text { in companies }\end{array}$ & 3 & 2.61 & 3 & 0.76 \\
\hline $\begin{array}{l}\text { 7. Deterioration of quality (Skill level) } \\
\text { of Human Resources working in } \\
\text { R\&D }\end{array}$ & 3 & 3.11 & 3 & 1.44 \\
\hline $\begin{array}{l}\text { 8. Current BEE policies will have a } \\
\text { negative effect on SA's future R\&D }\end{array}$ & 4 & 3.33 & 4 & 1.24 \\
\hline $\begin{array}{l}\text { capacity } \\
\text { 9. Lack of Direction and leadership in } \\
\text { Science Policy }\end{array}$ & 4 & 4.00 & 5 & 1.49 \\
\hline
\end{tabular}

Table 4: Summary table of hurdles facing the Private sector $R \& D$ in the next 20 years
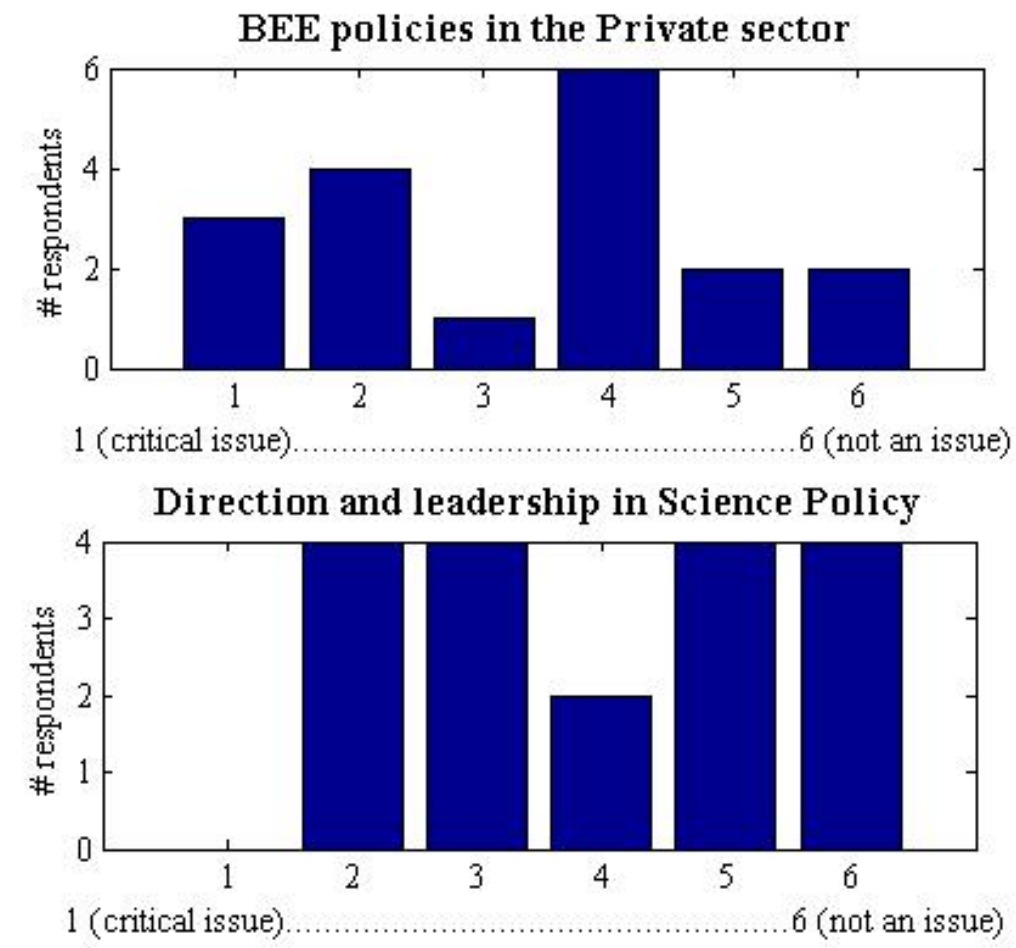

Figure 3: Private sector opinion regarding BEE policies and direction and leadership in science policy 
It can be concluded from the summary in Table 4 that the top four issues facing the South African private sector R\&D system are:

- The lack of a research culture, which is a hurdle to the development of R\&D capacity in the next 20 years

- Poor prospects for retaining and rejuvenating the human resources stock in the next 20 years

- Poor prospects for adequate funding for $R \& D$ in the public sector in the next 20 years

- A restrictive communication infrastructure

\section{CONCLUSION}

From analysis of the Delphi study, we can conclude that, according to aggregated group opinion, two similar themes emerge concerning the most pressing issues in all three of the R\&D sectors surveyed.

- The first theme is the poor prospects for retaining and rejuvenating researchers in the system. Linked to this is the perceived threat to the quality of human resources employed in the system.

- The second theme is the poor prospects for enough funding for R\&D in the next 20 years.

By contrast, there is a very low level of agreement (and thus uncertainty) over the effect of BEE policies on the future capacity of the system. This issue has the lowest level of consensus in all three sectors surveyed, and can thus be regarded as an issue that deserves further investigation. Reasons for disagreement might be that the issue is both complex and highly politicized in the South African environment.

A final conclusion from the results of the Delphi study is that, in general, a sufficient level of consensus was achieved in the second round survey. It must be remembered that the existence of consensus does not necessarily mean that the 'correct' answer, opinion, or judgement has been found. The real significance of the outcome of this study is that it identified areas (in this case, hurdles faced by the South African R\&D system) that the group of experts considered important.

\section{REFERENCES}

[1] HSRC, 2005. The National Survey of Research and Experimental Development: High-level key results. Pretoria.

[2] Piperakis, M., Pouris, A., 2006. The state of research equipment in South Africa: Towards best practice. South African Journal of Industrial Engineering, Vol. 17, No. 1, pp.75-90.

[3] DACST, July 2002. South Africa's National Research and Development Strategy. Government of the Republic of South Africa, Pretoria.

[4] NACI, 2002. South African Science and Technology: Key facts and figures, National Advisory Council on Innovation (NACI), Pretoria.

[5] OECD, 2002. Frascati Manual. Proposed standard practice for surveys on 
research and experimental development, Paris.

[6] Dalkey, N. C., dc Helmer, O., 1963. An experimental application of the Delphi method to the use of experts. Management Science, 9, 458-467.

[7] Dalkey, N.C., Rourke, D.L., Lewis, R., Snyder, D., 1972. Studies in the quality of life. Lexington Books, Lexington, Massachusetts.

[8] Delbecq, A.L., Van de Ven, A.H., and Gustafson, 1975. D.H. group techniques for program planning: A Guide to nominal group and Delphi processes, Scott-Foresman, Glenview, IL. 